\title{
Understanding diversity: a Dutch case study on teachers' attitudes towards their diverse student population
}

\author{
Daniel van Middelkoop* ${ }^{*}$, Hafid Ballafkih and Martha Meerman
}

\author{
${ }^{*}$ Correspondence: \\ d.van.middelkoop@hva.nl \\ Amsterdam University \\ of Applied Sciences, \\ CAREM, Postbus 1025 \\ 1000 BA Amsterdam, The \\ Netherlands
}

\begin{abstract}
Background: In the Netherlands, there has been a strong increase in diversity among students in recent decades. Even though access for previously underrepresented groups based on economic status, ethnicity or culture has been realised to a certain extent, differences in student performance between groups persist. Research shows that teacher performance influences student achievement and that this influence is more pronounced for 'non-western students'. This creates a need for reflection on the way teachers cope with their increasingly diverse student population. This paper explores the attitudes of Dutch teachers in higher vocational education towards their diverse student population and the translation of these attitudes into teaching practice.
\end{abstract}

Methods: Twenty-five teacher teams at two universities of applied sciences participated in this research. The teams came from a broad range of programmes that educate students for different future professions. A mixed method methodology was used to gather data, in which the qualitative method was most substantial. Focus group interviews on diversity and student achievement were held with each teacher team. Additionally, a questionnaire was distributed to all 274 participants, which was completed by 215 teachers. Data from the questionnaire were analysed using SPSS. In order to analyse the qualitative data we used AtlasTI. Because we applied a grounded approach, allowing teachers to form their own ideas on both diversity and student achievement, we used a similar approach in the first analytical phase. In a second phase, we compared the concepts arising from the grounded theory approach with concepts from the literature.

Results and conclusions: Around $40 \%$ of the teachers repudiated the influence of diversity on student achievement and did not take student diversity into account in their teaching practice. Problems regarding the student achievement of students or groups thereof are considered as something that the students, the educational institution or society at large should cope with, not teachers themselves. Of the teachers, $60 \%$ recognised diversity among students, but mainly based on students' shortcomings and perceived problems. A minority of this $60 \%$ not only recognised but also understood diversity's effect on student achievement. Teachers do not always translate this understanding into their teaching practice. They feel they lack the skills, knowledge or time to do so. Teachers seemingly translate their understanding of diversity into their didactic and pedagogical approaches only when these conditions are met.

Keywords: Diversity, Student achievement, Higher education, Teachers, Attitudes 


\section{Background}

The number of students enrolled in higher vocational education in the Netherlands has grown significantly in recent decades, from approximately 200,000 in 1978 to over 400,000 in 2010 (CBS 2013), mirroring a European and arguably a global trend towards 'massification' in higher education (Altbach et al. 2009). In their UNESCO report, Altbach et al. (2009, p. 7) state that 'without question, the coming period will be dominated by the implications of mass access. Massification of higher education leads to pressures on both the affordability and quality of education'.

Another implication of massification is the diversification of the student population. In the Netherlands, there has been a strong increase in diversity among students in recent decades. In the 1970s, there was a strong increase in the number of female students and students from the lower socioeconomic classes (Beerkens-Soo and Vossensteyn 2009). Since the 1980s, the number of students of a non-western ethnicity ${ }^{1}$ has increased (Middelkoop and Meerman 2014; Jong 2014; Wolff 2013). There has been an increase not only in ethnic and cultural diversity, but also in terms of socioeconomic status and educational background (CBS 2013; Wolff 2013).

Even though access for previously underrepresented groups based on economic status, ethnicity or culture has been realised to a certain extent, differences in student performance between groups persist. Mirroring trends in other western countries (Carey 2008; Shavit, Arum and Gamoran 2007; Meeuwisse 2012), the performance gap between different ethnic/cultural groups seems to be widening rather than narrowing (Wolff 2013; Zijlstra et al. 2013). Recent government-funded programmes to improve the achievement of previously underrepresented student groups have proven to be ineffective, because the role of the teacher has been largely overlooked (Middelkoop and Meerman 2014; Zijlstra et al. 2013).

Research shows that teacher performance influences student achievement. ${ }^{2}$ Two meta-studies (Hattie 2009; Marzano 2003) have shown that the influence of the teacher is significant, even though the exact amount of influence is part of an ongoing scientific and educational debate (Snook et al. 2009, 93). Research in the Netherlands indicates that the influence of the teacher is even more pronounced for non-western students (Severiens 2011; Jong 2014). This creates a need for reflection on the way teachers cope with their increasingly diverse student population. In this paper, the way teachers think of and deal with increased diversity among students is discussed.

The following research questions are central to this paper:

(1) What are the prevalent attitudes among teachers towards diversity in the student population?

(2) To what extent are teachers' attitudes towards diversity in the student population translated into their teaching practices?

\footnotetext{
${ }^{1}$ In the Netherlands, the terms autochthonous and allochthonous residents are commonly used. Allochthonous (in Dutch: allochtoon) refers to migrants: they or at least one of their parents were born in another country. It is most commonly used to refer specifically to non-western migrants. Autochthonous refers to the 'ethnic Dutch' population.

${ }^{2}$ Of course this is dependent on one's definition of student achievement or study success. Definitions of study success given by teachers in our research will be presented in a different paper.
} 


\section{Theoretical framework}

We first consider a number of definitions of diversity before discussing its influence on student achievement. We then zoom in on the influence of the teacher when it comes to student achievement and the importance of teachers taking diversity into account in their teaching practice.

\section{Diversity and student achievement}

Although in its most literal form diversity simply means 'variety', there are different forms of variety (Roberson 2006, 212-236). A distinction can be made between diversity in observable or readily detectable attributes-such as race or ethnic background, age or gender-and diversity with respect to non-observable or underlying attributes, such as education, technical abilities, functional background, tenure in the organisation, socioeconomic background, personality characteristics, intelligence or values (Cummings et al. 1993; Jackson et al. 1995, 204-261; Tsui, Egan and O'Reilly 1992, 549-579; Milliken and Martins 1996, 402-433). Observable and non-observable attributes can overlap: the majority of an ethnic group can have a certain socioeconomic background or a certain set of perceived values. Furthermore, the difference between observable and non-observable attributes is not always very clear-cut.

In the Dutch context, differences between groups based on both observable and nonobservable attributes can be noted. Most often diversity is related to observable ethnic differences, focusing on differences between ethnic Dutch and non-western groups (Wolff 2013; Zijlstra et al. 2013; Jong 2014). The debate on ethnic differences in the Netherlands tends to focus on deviations from the norm, creating a tendency to distinguish between the ethnic Dutch population and the mainly non-western minorities (Gorashi 2006), thus ignoring differences between ethnic minority groups as well as individual differences within these groups. There is also a tendency in the debate to attribute a socioeconomic disadvantage to all minority groups. Both these tendencies lead to categorical thinking when it comes to diversity in the Netherlands (Gorashi 2006).

More recently, gender diversity has received renewed attention in the educational debate: female participation and success rates in education seem to have surpassed those of males, and male students are perceived to lag behind where educational achievement is concerned.

Invisible or less visible attributes are also important in the Dutch context, even though they often overlap with visible characteristics. Socioeconomic background is considered to influence students' chances of success in higher education. Differences in performance can also be perceived between students whose parents have studied and students who can be considered 'first-generation students'. Educational background (prior to higher education) can also impact student achievement: especially students coming from institutions of intermediate vocational education have higher dropout rates. And the groups overlap: many of these students are also from non-western ethnic backgrounds (Zijlstra et al. 2013; CBS 2013).

\section{Diversity and education}

Thus, student achievement differs between groups of students: diversity matters. But should the educational system take these differences into account? When applying a 
meritocratic line of thought, this question is most commonly answered negatively. The meritocratic approach is based on the idea that talent, motivation and effort determine the measure of success students can attain (Verhaeghe 2011, 4-22; Pels 2007). All students are offered the same opportunities, and it is up to them to take advantage of these opportunities. However, a meritocracy only functions as such when all students have the same capital. This is often ignored in both the theoretical debate and the educational practice (Verhaeghe 2011, 4-22; Nussbaum 2011). Students have different interests, learning needs and talents, due to their specific backgrounds, experiences and social contexts (Waslander 2006). The starting positions of students differ, with some students better adapted to the mainstream teaching practice in higher education than others (Bourdieu and Passeron 1990; Bowles and Gintis 2002, 3-30; Bowles et al. 2009). A uniform meritocratic approach does not take these differences into account and as a result these differences are often sustained or enlarged (Broek 2009; Bourdieu and Passeron 1990; Meerman et al. 2009). Not acknowledging differences means that those students who do not belong to the 'normal' group will have to adapt or face the consequences. Students' talents that do not easily fit in the dominant discourse are not recognised or rewarded. These students are therefore at risk of underperforming or dropping out. Diversity is thus not a neutral term, used only to describe either observable or nonobservable differences between groups. It holds within its definition issues of power and social inequality (Andersen and Collins 1995; Snowden 2004, 291-303; Zepke and Leach 2007, 655-668).

An approach that takes these issues of power and social inequality into account is the capabilities approach. In her book Creating Capabilities, Martha Nussbaum states that the capability approach 'takes each person as an end, asking about the opportunities available to each person. It is focused on the choice of freedom' (Nussbaum 2011, 18). Nussbaum describes capabilities as the ability to use opportunities and choose which ones to use. She describes ten key capabilities (ibid., 33-34) and states that 'an ample threshold of ten central capabilities is required' (ibid., 32).

Following this line of reasoning, the educational system should take into account differences between students or groups thereof into account. All students entering higher education should be enabled to lift themselves above the threshold of development for their capabilities. Central to this approach is the notion of fair inegalitarianism, as a form of equality that includes the notion of fairness in the sense that it implies special provisions for the least advantaged members of society (Vouyoukas 2002). When considering the wide range of existing capabilities in a student population, it is up to the school and the teachers to recognise and act upon these differences in order to enable students to develop their capabilities.

\section{Teachers and student achievement}

Following the line of reasoning from Martha Nussbaum's capabilities approach, diversity should be taken into account in the educational system. But how? To find an answer to that question, we look at what determines student achievement, using the work of Robert Marzano (2003). In a meta-analysis on the results of 35 years of research he gives an overview of what determines student achievement in the American educational 
system. He distinguishes between three levels of factors that together determine student achievement:

1. School-level factors: factors that are 'under the jurisdiction of the school as a whole'. Changes in these factors are usually a result of formal or informal policy decisions (Marzano 2003, 15).

2. Student-level factors: accounts for the lion's share of variance in student achievement. But effects can be overcome by actions at the level of the school or the teacher (ibid., 125).

3. Teacher-level factors: the most influential category, comprised of factors determined by the impact that a teacher can have on student achievement (ibid., 71). Marzano identifies instructional strategies, classroom management and classroom curriculum design as teacher-level factors.

In an even more extensive meta-study, John Hattie (2009) also concludes that teachers strongly influence student achievement. ${ }^{3}$ Both Hattie and Marzano describe in-school factors. Student achievement is also strongly influenced by factors outside the influence sphere of the school. Marzano states, however, that outside influences 'can be mediated by school-based interventions' (Marzano 2003, 123). The potential influence of the school is therefore substantial, presumably especially so for those students who lack a certain threshold of capabilities when starting in higher education.

\section{Teachers' attitudes towards diversity}

Research shows that teaching practices reflect teachers' attitudes, which in turn reflect teachers' own experiences and backgrounds (Cabello and Burstein 1995, 285-294). Teachers have a big influence on student achievement. This implies that student achievement is influenced when teachers do or do not take diversity into account in their teaching practice.

We consider attitudes as 'manifestations of unconsciously held views of expressions of verbal commitments to abstract ideas that may be thought of as part of a general ideology of teaching' (Thompson 1984, 105-127). An attitude in education can be seen as a source of ideology, knowledge and values that guide teachers in their teaching practice. Research suggests that teachers' attitudes affect both their judgments of students and their behaviour in the classroom (Ashton and Webb 1986; Pajares 1992, 307-32; Yang and Montgomery 2013, 27-37; Gay 2013, 48-70).

In order to further specify teachers' attitudes towards diversity, we build upon the theoretical notions of Helms (1990), Cox (2001) and Meerman et al. (2009). Based on these notions, three types of attitudes towards diversity can be identified:

1. Repudiation of the influence of diversity on student achievement.

2. Recognition of the influence of diversity on student achievement.

\footnotetext{
${ }^{3}$ The importance of the role of the teacher can be seen not only when looking at success, but also when looking at students not achieving success. Zepke and Leach 2007, 655-668) state that teachers and teaching are key factors in student retention.
} 
3. Understanding the effects of diversity and their attitude towards diversity on student achievement. $^{4}$

Earlier research suggests the first attitude is most prevalent among teachers in the Netherlands (Meerman et al. 2009). This 'cultural blindness' (Cabello and Burstein 1995, 285-294) might be due to the emphasis on equal worth and equal treatment in Dutch education, which seems to stem from a predominantly meritocratic view on education. ${ }^{5}$ This focus on equal treatment originates from a liberal view of egalitarianism, which is closely linked to the notion of meritocracy in the sense that opportunities are given to all in order that they may 'advance' in society (Vouyoukas 2002).

Research also shows that a large percentage of teachers adhere to the second attitude (Meerman et al. 2009). These teachers acknowledge the influence of diversity on student achievement, but have limited knowledge of its effect. They can be said to 'accept the general idea of culturally responsive teaching but may not know what it means for practical application' (Gay 2013, 48-70). Research suggests that teachers who adhere to the second attitude might be prone to stereotyping by neglecting the significance of individual differences within cultural or ethnic groups (Meerman et al. 2013; Nieto 1992).

Teachers with the third attitude towards diversity are a minority in most teacher teams (Meerman et al. 2009, 2013). These teachers can be said to have an understanding of students' backgrounds and characteristics (Gay 2002, 106-116), ${ }^{6}$ without stereotyping students according to their backgrounds or characteristics. They acknowledge the many different capabilities of students and the need to take those capabilities into account in their teaching.

\section{Acting on diversity}

With attitudes of the first type, it is very unlikely teachers act upon the diversity in the student population, as this attitude ignores questions of social inequality and power between students. This in turn leads to a uniform approach to all students. However, teachers' attitudes of the second and third types do not automatically lead to teachers acting upon their recognition or understanding of diversity (Meerman et al. 2009). When they do translate their attitude into their teaching practice, however, we can classify those actions using the teacher-level factors formulated by Marzano.

\section{Instructional strategies}

Using instructional strategies, a teacher enables students to gain knowledge and skills. (Marzano 2003). Student diversity influences the effective use of instructional strategies

\footnotetext{
${ }^{4}$ In earlier research we found the typology to be useful as a theoretical construct that provided a framework to make sense of teachers' attitudes towards diversity (Meerman et al. 2009). The typology has been widely used to structure attitudes towards diversity (e.g. Thompson and Carter 1997; Roberson 2013). We chose not to question the typology as such in this paper. We focused on enriching the knowledge about these three types of attitudes, underlying rationales for the attitudes as expressed by teachers as well as consequences for teaching practice.

${ }^{5}$ For an extensive discussion on equity egalitarianism and fair inegalitarianism, see Vouyoukas (2002) and Muhammad (2015). For an insight into similar prevalent attitudes in other countries, see e.g. Gay (2010, 143-152), Yang and Montgomery (2013, 27-37), Zepke and Leach (2007), 655-668).

${ }^{6}$ Geneva Gay, among others, mainly refers to cultural and ethnic diversity in her work; attention to other types of diversity, such as gender or social class, can however be assumed to require a similar understanding of the background and characteristics of students.
} 
of teachers in a number of ways. One of the strategies, for instance, is the way that cooperative learning is organised. Cooperation can be less effective in mixed groups, but working in mixed groups can also enrich the learning experience, as students learn to identify and communicate with 'Others'. Diversity influences more categories of instructional strategies, such as non-linguistic representation, setting objectives and providing feedback, or reinforcing effort and providing recognition (Middelkoop and Meerman 2014).

\section{Classroom management}

Differences between students lead to students having different needs, which influences the demands made on teachers' effective classroom management. Taking diversity into account therefore matters also when it comes to classroom management. ${ }^{7}$ Differences between students create the need for different forms of interaction between teacher and student, as well as for the ability to act upon differences in intrinsic and extrinsic motivation, use of language, forms of interaction, learning styles, etc. (Middelkoop and Meerman 2014).

\section{Classroom curriculum design}

An increasingly diverse student population creates the need for critical reflection on the curriculum. Different starting positions and learning styles can create the need for changes to the structure in which content is presented to students. ${ }^{8}$ But a critical reflection on the curriculum can also stem from changes in the profession for which students are being prepared. When dealing with diversity is a key aspect of the future profession of the student, this impacts the curriculum, for instance through the cases that are being used or through specific courses such as intercultural communication. Societal changes can also be a catalyst for changes to the curriculum. Through the curriculum, teachers can address issues like societal inequality or discrimination (Middelkoop and Meerman 2014).

\section{Methods}

The data used in this study are derived from a wider study on diversity and student achievement (Middelkoop and Meerman 2014, 2015). From December 2010 to October 2012, 274 teachers in 25 teacher teams at two universities of applied sciences in major cities in the Netherlands were followed. These cities can be characterised as 'majorityminority cities' (Crul et al. 2013), in which the ethnic Dutch population is a minority. This is mirrored in the student populations, with around 50 percent of students at these universities being of non-Dutch ethnic origin (CBS 2016).

The teams chose to participate in this research; the teachers and/or the team manager wanted to discuss diversity in relation to student achievement. The teams came from a broad range of programmes that educate students for different future professions. Some

\footnotetext{
${ }^{7}$ Marzano states that 'different classrooms will have different rules and procedures depending on the needs and dispositions of the teacher and the students' (2003, p. 89).

8 This does not mean that the expected level of achievement is lowered-the curriculum is structured differently; the expectations of students are not lowered.
} 
teams actively asked to be part of this research, whereas others were invited to participate by their institution's management. The teams comprised on average 11 teachers. As we chose to interview existing teams, we had no influence on their composition regarding age, sex, professional status, etc. A mixed method methodology was used to gather data, in which the qualitative method was most substantial.

The methodology builds upon the earlier research and methodological experiences of the research group HRM and Diversity (Meerman et al. 2009). One of the conclusions of this research was the lack of urgency to take into account diversity in the student population and in teacher teams. By connecting diversity to the primary process, in this case student achievement, we sought to overcome this experienced lack of urgency.

A focus group interview on diversity and student achievement was held with each teacher team; the interviews lasted for an average of $2 \mathrm{~h}$. We conducted a second focus group interview with the teams after 6-12 months. Due to time and organisational constraints experienced by the teams, only 18 of the 25 teams could be interviewed a second time. The transcripts of the group interviews are the main sources of data on which the results of this paper are based. A questionnaire was also distributed to all 274 participants prior to the first group interview. The questionnaire was completed by 215 teachers. The main aim of the questionnaire was to gain input from the participants which was used during the focus groups interviews. Additionally, the questionnaire provided us with data that yielded useful insights in the attitudes towards diversity of the participants. The results of the questionnaire can not be generalised to the target population because the teachers opted-in for the research. This makes the sample a 'non-probability sample which questions the generalisability of the quantitative findings' (see e.g., Beulens et al. 2015, 7).

Each group interview was unique, taking as a starting point the situation of each teacher team. Using that situation, we discussed dilemmas, problems and observed practices regarding diversity and student achievement. As researchers we thus did not observe from outside the teacher teams, but tried to find solutions and contributions together with them. The researchers functioned both as enablers of this process and as experts in diversity and student achievement.

\section{Data analysis}

Data from the questionnaire were analysed using SPSS. In order to analyse the qualitative data we used AtlasTI. Because we applied a grounded approach, allowing teachers to form their own ideas on both diversity and student achievement, we used a similar approach in the first analytical phase. In a second phase, we compared the concepts arising from the grounded theory approach with concepts from the literature.

Quotations used in this paper were chosen because we consider them to be exemplary of the general picture that arose from the data. As we wanted the participating teachers to talk freely, we processed the information we gathered from teacher teams or individual teachers anonymously.

\section{Findings: teachers' attitudes towards and teaching practices for diversity}

In the first part of this section, we discuss the attitudes of the teachers in the 25 teams. In the second part, we focus on the teaching practices teachers use for diversity. 


\section{Teachers' attitudes towards diversity}

When asked in the questionnaire whether they distinguished between normal and atrisk students, $59 \%$ of the teachers said that they do make this distinction. Although this is the majority of the teachers participating in our research, it also means that a sizeable minority $(41 \%)$ do not make distinctions between normal and at-risk students. Female teachers make a distinction more often than male teachers (63 and 58\%, respectively). We did not find meaningful differences based on age, years of teaching experience or type of contract.

Those teachers who did distinguish between normal and at-risk students were asked how they recognised the latter. Up to three identifying characteristics could be selected by the teachers. The teachers' responses were categorised in one of eight overarching characteristics, which accounted for approximately $80 \%$ of the answers. The other $20 \%$ were so diverse they could not be categorised in an overarching characteristic. The eight characteristics were:

1. Motivation to study

2. Personal problems

3. Poor linguistic skills

4. Ability to study

5. Study credits

6. Intelligence

7. Cultural \& ethnic differences

8. Starting level (the level of skills students possess when starting their study).

The characteristics are ordered by the number of times they were mentioned by teachers. Over one-third of the teachers mentioned motivation; this was 2.5 times more often than the second most mentioned characteristic, namely personal problems. Motivation, personal problems, language problems and study skills made up just over two-thirds of the answers. Cultural \& ethnic differences and starting level accounted for less than $5 \%$ of the answers. Based on these characteristics, one might conclude that teachers who do distinguish between normal and at-risk students, do not do so on observable characteristics like ethnicity. ${ }^{9}$ Students are identified on the basis of non-observable or hardly observable characteristics, such as motivation or personal situation.

However, when we look at the dilemmas and problems the teachers mentioned in the questionnaire, a different picture emerges. Again, many dilemmas and problems observed by the teachers are related to non-observable characteristics, such as motivational problems, language problems, a lack of study skills and the cognitive capabilities of students. However, some of these general problems are considered to be more present in certain student groups distinguished on the basis of observable characteristics. Approximately $16 \%$ of the dilemmas around student achievement experienced by teachers can be classified as related to specific groups of students.

\footnotetext{
${ }^{9}$ As already mentioned in the methodology section, the student population at the universities of applied sciences in which these teachers work is highly diverse, with around $50 \%$ of students being of non-Dutch ethnic origin. The institutes do not register ethnic diversity on the level of studies, so no specific information regarding student diversity can be given per teacher team.
} 
One problem is the educational background of certain groups of students. Many teachers feel that students are ill prepared for higher vocational education. This problem is mainly related to students who do not go directly from secondary education to higher vocational education, but who first follow a programme in intermediate vocational education. These students are thought to be ill prepared for studying independently (selfstudy, without guidance from the teacher) and have trouble with theoretical courses, even though they can sometimes benefit from their more practical approach in some courses. Language problems are also more often ascribed to this group. Another problem concerning student achievement mentioned by many teacher teams concerns the problematic personal situation of some students. The teachers almost always related this to non-western students, who are often first-generation students; that is, their parents have no experience of studying and teachers feel that these parents are less enabled to support their children. But teachers also mentioned problems with students who, due to family circumstances and responsibilities, cannot give priority to their study.

Having used the quantitative data to provide a general picture, we now use the qualitative data to paint a richer picture of the different attitudes of teachers towards diversity. We do so using the three types of attitudes towards diversity introduced in the theoretical framework.

\section{Repudiation of the importance of diversity}

The quantitative data show that a large percentage (over 40\%) of the teachers did not make a distinction between 'normal' and 'at risk' students. Does this mean these teachers repudiate the influence of diversity on student achievement? The findings from the qualitative analysis do seem to point to that conclusion. In the group interviews, all teachers recognised the presence of diversity among students, but many teachers found this diversity should not be taken into account in day to day teaching. According to these teachers, the diversity among students did not-or should not-have an influence on student achievement and the way teachers acted. This attitude of repudiating diversity was found among teachers in all teams that participated in the research. This is remarkable, as only teams that were interested in discussing diversity participated in the research; it seems plausible that in other teams, even more teachers will have this attitude.

When diversity and its influence on student achievement was discussed during the team interviews, teachers often related the recognition of diversity to loss of quality (related to educational standards), stigmatisation and discrimination, and the loss of western values. There was noticeable hesitance to discuss diversity related issues, and the discussions we had in the teacher teams were often emotionally charged and sometimes led to tension between the participants. An example comes from one of the team interviews, when in the last $10 \mathrm{~min}$ of a $2 \mathrm{~h}$ interview a teacher made the following statement, only to be immediately corrected by a colleague:

Teacher 1: It is terrible, but when looking at the list of new students, I can see who will make it and who will not. Just look if the last name is of non-western origin (...) 9 out of 10 of those will either not show up or drop out.

Teacher 2: I think this is something we cannot change (...). We try to make them feel welcome, I do not feel we are prejudiced. 
This hesitance occurred almost exclusively when debating ethnic or cultural diversity. Differences based on gender or the earlier educational trajectories of students were easier to discuss, and teachers seemed more willing to change their teaching practice according to, for instance, the needs of male or female students.

Teachers often repudiate the importance of diversity because they adhere to the ideal of equality. The content of the curriculum or the style of teaching is non-debatable, according to the teachers. They argue that it is up to students to master the content, by using their intelligence and making an effort. The different sets and levels of capabilities of students starting out in higher education are not recognised by these teachers. They value the equal worth of students and translate this into the need for equal treatment, or as one of the teachers put it:

Ifeel we are discriminating a bit, when we focus too much on the differences between non-western and Dutch students. I don't care whether they are non-western or Dutch (...) I'm not going to treat them differently. You either pay attention [in the classroom] or you do not. We have our norms and values here, you are here, you will have to adapt. End of story.

Other teachers did not recognise the influence of diversity on student achievement as a result of their vision on the role of the teacher. These teachers acknowledged that there are differences between students, but said that they feel it is not up to them to act upon those differences. These teachers seemed to have a quite specific and somewhat traditional ideas about what teaching entails and what the future profession of the students entails-there is one way to function in that profession, and there is also only one way to teach this correctly. If students cannot master that way of functioning, they do not belong in higher education, according to those teachers. Within this group we can again recognise a meritocratic way of thinking, where the threshold is set at a certain levelbased on the needs of the labour market-and those students who possess the 'right' qualities will make it. ${ }^{10}$

We conclude that a considerable number of teachers repudiate the influence of diversity on student achievement, because they adhere to a liberal egalitarian/meritocratic educational ideal. If there is a problem regarding the student achievement of certain groups of students, they consider it to be the problem of the students, the educational institution or society at large, not the teachers themselves. According to these teachers, students who lag behind or drop out do so because they do not have the capabilities to finish a study in higher education. Many of these teachers advocate stronger selection 'at the gate', that is, they favour admitting only students who meet the 'necessary' criteria, namely the capabilities that are rewarded in the dominant culture in the educational system and labour market.

\section{Recognising the influence of diversity}

The $60 \%$ of teachers who made a distinction between 'normal' and 'at risk' students, mainly related problems and dilemmas leading to lower student achievement to three groups: boys, non-western students and students coming from institutions of

${ }^{10}$ Although these teachers seemed to view this threshold as quite 'absolute', it often remained unclear what the threshold consisted of and what criteria determined it. 
intermediate vocational education. The same picture arises from the group interviews. All groups are perceived by teachers to have their specific set of problems. The lower student achievement of boys, for instance, is perceived to be caused by a lack of intrinsic motivation and planning skills, leading to a low and ineffective study effort. According to these teachers, boys' brains are not ready for studying, as opposed to those of girls.

The lower student achievement of boys is often linked to the lower student achievement of non-western students. Especially non-western boys are perceived to have lower achievement. The group of non-western students is most often seen to be underachieving, even though many teachers stressed the need for a broad (i.e. not only an ethnic) definition of diversity. The non-western students were sometimes perceived as one group, but more often the teachers differentiated between, for instance, non-western students of Moroccan or Turkish origin and students from the Netherlands Antilles.

These non-western students are perceived to have many problems, for example regarding their mastery of the Dutch language and their lack of studying skills. Knowing how to use and deal with feedback was the most frequently mentioned problem. But the motivation of this group is also often perceived as low. They are supposedly extrinsically motivated, leading to an 'unproductive' attitude, according to one of the teachers:

These [non-western] students show a different behaviour compared to what we are used to. They are less direct, do not dress correctly, do not turn in their homework on time and when confronted with the consequences, they try to negotiate.

The third and last group that teachers distinguished consists of students coming from institutions of intermediate vocational education. The problems the teachers related to this group are broadly the same as those related to non-western students. In a number of interviews, teachers stressed that these groups overlap. Many non-western students come from intermediate vocational education before moving on to higher vocational education. Problems related to this group of students, however, are more often linked to a lack of studying skills and less often to motivational problems.

\section{Understanding the influence of diversity}

A minority of the teachers said that they understand the influence of diversity on student achievement. They did not see diversity as something 'extra', but as an intrinsic part of teaching. According these teachers, a seeming lack of motivation among, for instance, Dutch-Moroccan male students can be caused by the fact that they do not know how to study. They feel insecure and, as a result, are indifferent and unmotivated. Moreover, these teachers did not focus on the problems of certain groups of students, but also identified the opportunities that a diverse student body has to offer. They did not automatically presume that minority groups are at a disadvantage. Students are not less motivated or talented, but possess other talents or can be motivated in different ways. There are, in short, different ways to develop the capabilities needed to study successfully.

Teachers who understand the influence of diversity were often the ones who stressed that taking diversity into account is not the same as stigmatising groups, or favouring certain groups. They said they were aware of cultural differences between groups or differences in the home situation, without resorting to stereotypes. By taking diversity into account, teachers argued that students can be given the opportunity to be successful, 
using their unique characteristics and talents. This does not lead to a lower educational quality, as one of the teachers explained:

The level students have to reach remains the same, and all the things we teach them also remain the same. But [we as teachers] will have to guide people with different backgrounds to this level in different ways.

Teachers who understand the influence of diversity could be said to use a capabilities approach. They have insight into the individual capabilities that students have and know how to develop these capabilities, while keeping in mind the characteristics of groups of students. These teachers were a minority in all the teacher teams that participated in the research. This minority can, however, act as a catalyst for increased attention to diversity among other teachers. As one teacher explained:

My two colleagues are now being asked for their expertise when there is a problem, for instance regarding certain Moroccan male students. (...) The tendency in the team to solve these kind of problems on one's own seems to have lessened.

This was not always the case. It became clear during the interviews that the debate on diversity was often an ideological one. When other teachers in the team spoke out clearly against the idea of taking diversity into account, based on their belief that this was necessary to provide all students with equal opportunities, the debate often became quite heated, with both parties unwilling to question their own beliefs. ${ }^{11}$

\section{Teaching practices for diversity}

Having gained insight into the attitudes of teachers towards their diverse student population, we now focus on whether teachers act upon these attitudes in their teaching practice.

For obvious reasons, the group of teachers who did not recognise the influence of diversity on student achievement, did not use this in their teaching. However, also teachers who did recognise or understand the influence of diversity, did not always translate this into their teaching practice. Some of these teachers said that they feel they should take diversity among students into account, but do not have the didactic or pedagogical skills to do so. Other teachers said that it is hard to judge what influence aspects of diversity have, let alone know how to act on the perceived differences among students. Many teachers mentioned the question of whether to mix groups of students during assignments, and said that they did not know whether or not this benefits students, or under what conditions. As they feel they do not have the capacity to deal with diversity in their teaching practice, they resort to a uniform, often content-driven approach to their students.

Other teachers said that they feel they do not have time to use diversity in their teaching practice. This can be related to using a differentiated approach in the classroom, but also for instance to providing extra assistance to students who need it. In most of the team interviews, teachers emphasised the limits of what they can offer students: 'We do not have the possibilities to give the weaker students extra guidance, or to offer different teaching methods. There is no time for that'

${ }^{11}$ Whether teachers who understand diversity get a chance to act as catalysts and be heard by their colleagues is likely to be influenced by the internal power relations in the team and the status of the teachers in the group. 
This barrier to using diversity is related not only to time, but also to the authority to make decisions about how to teach. Many teachers said they feel that they have an increasingly limited say about how they organise their own teaching. ${ }^{12}$ In this case, attention to diversity remains fragile and is easily 'forgotten' when faced by seemingly more pressing issues.

Finally, we focus on the teachers that do take diversity into account in their teaching practice. At the individual level, the attitude of teachers towards diversity can translate into the didactic and pedagogical practices of teachers. Some teachers who understand diversity among students emphasised the need for a differentiated approach towards students. These teachers try to anticipate the diverse range of capabilities of their students, without resorting to stereotyping regarding certain groups, that is, assuming that students have certain problems because they belong to a certain ethnic group. Concerning pedagogy, stimulating social cohesion among students is seen as important by these teachers. They see a need for students to get to know each other's backgrounds and cultures. They deem this important because of the professional context in which the students will be working in their future careers; for many professions, coping with a diverse environment is part of the job. ${ }^{13}$ But the societal need is also stressed: in a society in which tensions between different groups seem to be increasing, there is a need to understand the 'Other'. Some teachers try to achieve this by stimulating students to get to know each other through either classroom-related or extracurricular activities. Using role models for different groups of students - namely for groups of non-western students, as well as for boys or girls-is also seen as important. For these role models to be present, a diverse teacher team seems a necessity.

Regarding the curriculum, some teachers questioned its dominant (western) frame of reference, and advocated the need to include different frames in the curriculum. This was often accompanied by stressing the need for attention in the curriculum to intercultural communication. It was argued during the interviews that providing different frames of references has two benefits. First, the presence of different frames provides a more level playing field for students. A predominantly western frame can, for instance, put non-western students at a disadvantage because they identify with this frame to a lesser extent. Second, attention to different frames of reference in the curriculum also contributes to better qualified professionals in the long run, as the work field is also becoming more diverse:

I notice that as a teacher, I'm becoming more humble. I wonder whether the way we train [our students], focused on the white middle-class, really helps Turkish and Moroccan boys, because they have a different way of working. And I think Dutch companies will have to adapt to their way of working in the coming 10-15 years. (...) It would be interesting to see if we could critically look at our frame of reference and see if we can use other frames.

12 This lack of experienced professional authority or teacher agency was an extensive part of our wider research, and will be discussed in another paper.

13 This seemed to differ depending on the orientation of the study: teachers in social or medical studies stressed this aspect more often than their colleagues in technical or economic studies. 
However, most teams did not want to make changes in this regard. It often came up during the interviews, with a small number of teachers being in favour of changing the curriculum, but most team members opposing it.

\section{Conclusions}

A sizeable share (40\%) of the teachers participating in the research choose not to make a distinction between 'norm' and 'at risk' students. Findings from the group interviews suggest many of them do so because they repudiate the importance of diversity. They adhere to a liberal egalitarian/meritocratic educational ideal. As a result, they did not feel the need to take differences among their students into account in their teaching practice. Differences in the development of capacities as described by Nussbaum were not taken into account by those teachers.

A majority of the teachers (60\%) did choose to make distinctions between students. Based on the qualitative data it can be said they recognise the influence of diversity. However, many of them perceived those groups of students that are different from the normal students as being in need of assistance. Their shortcomings related to cognitive and motivational issues need to be remedied. These teachers did not focus on the potential added value of diversity or the capabilities these students might have that normal students do not possess. Only a small amount of teachers understands the influence of diversity. They feel they recognise the capabilities students have and know how to develop these capabilities, using the individuality of students, but keeping in mind the characteristics of groups of students.

In most teams we encountered a combination of the three attitudes of teachers towards diversity. During the discussions we could therefore clearly observe the tension in teacher teams between the wish to adhere to a liberal egalitarian/meritocratic ideal of equal opportunities, and the wish to give a diverse student population the means to study successfully by taking into account the differences in capabilities among students.

Looking at the translation of teachers' attitudes into teaching practice, it is obvious that teachers who repudiate the importance of diversity do not take diversity into account in their teaching practice. However, also teachers who do recognise or understand the influence of diversity, do not always translate this into their teaching practice. According to the teachers, this is because of a lack of skills, knowledge or time to do so. If this is not remedied, it will be hard for teachers to translate their understanding of diversity into their didactic and pedagogical approaches. This might be one of the reasons why such a limited number of teachers in the study seemed to effectively use their understanding of diversity in their teaching practice. Further research on these conditions, however, seems to be necessary to fully understand their influence on teacher practice. Allowing teachers to use that understanding is important, as these teachers, although relatively few in number, could act as catalysts in teacher teams to initiate or strengthen the attention paid to diversity.

\section{Limitations}

This study provided valuable insights in attitudes of Dutch teachers towards diversity. There are however some limitations of this study. We look more closely to three limitations of this study, because we feel they should be taken into account in further research. 
First, it is worth noting that we focused on group interviews and discussed teacher attitudes in these group discussions. Although this provided us with a rich set of data, the approach used does have its limitations. Discussing a sensitive topic such as diversity brings with it issues regarding both formal and informal power relations between teachers in the teams. Some teaches might not have felt 'save' enough to express their opinions openly, others might have stayed away for the same reason. Combining group interviews with individual interviews (rather than a questionnaire) might help remedy this limitation in future research.

Second, we discussed teacher attitudes and the translation of these attitudes into teaching practice. The attitudes and account of their teaching practice teachers 'presented' during the group interviews might not always correspond with reality. Future research might benefit from combining individual and group interviews with observation of teaching practice.

Third, the study is quite context specific, not only for the Netherlands, but for the urban areas of the Netherlands. Although more recent work (in progress) of our own research group and findings from earlier research in other countries, as described in the theoretical framework, suggest that the issues and dilemmas regarding dealing with diversity in higher education transcend the Dutch and urban context, we cannot-on the basis of our data-generalise to other contexts. Further and broader research allowing for comparisons between these contexts is recommended.

\section{Discussion}

It seems quintessential to stimulate the debate about diversity in teacher teams if the need for teachers to take diversity into account is acknowledged. Only by discussing the relevance of diversity with colleagues and learning first-hand from colleagues can teachers start to recognise and understand the influence that diversity has on student achievement. But not all discussion or debate leads to the recognition of diversity. It is possible, as we observed during the team interviews, that teachers become mired in an ideological debate, in which the rhetorical skills of the participants determine whether the meritocratic arguments or the arguments based on a capabilities approach are more convincing. Teachers need to be able to discuss issues regarding diversity on the basis of correct information about student achievement, something which was often lacking in the teams we interviewed. Reliable information enables teachers to see which students underperform, and can consequently hold an informed discussion about both the causes of and the solutions to the situation. As this is often context-specific information, teachers and managers should be provided with detailed information by the institution, and be given the opportunity to decide on possible teaching practices.

Debate or discussion in teacher teams is essential, but as a beginning, not an end in itself. The debate should be followed by actions-preferably initiated by the teachers themselves-that enable teachers to translate their understanding of diversity into their teaching practice. Teachers who are unable to make this translation because they lack the relevant knowledge should be given access to knowledge and established practices in dealing with diversity in teaching practice. The examples we described of teachers who understand diversity and use that understanding accordingly, can act as inspiration, but it is important to note that there is no 'one size fits all' or 'best' way for teachers to deal 
with diversity. Teachers need time and professional autonomy to come up with ways of dealing with diversity that do justice to the diversity among students and fit the context in which the teacher team and students operate. Both time and professional autonomy therefore seem to be preconditions for making the translation into teaching practice.

\section{Authors' contributions}

$\mathrm{DM}$ and $\mathrm{MM}$ designed the research project in collaboration; $\mathrm{DM}$ conducted the interviews, $\mathrm{MM}$ and $\mathrm{HB}$ were present at a number of interviews in an observer role. All three authors analyzed the data, with DM and MM focusing on the qualitative analysis and $\mathrm{HB}$ on the quantitative analysis. DM wrote the first draft of the paper; all three authors added to and edited subsequent versions. All authors read and approved the final manuscript.

\section{Authors' information}

Daniel van Middelkoop and Hafid Ballafkih are both senior researchers at the research group HRM at the University of Applied Sciences in Amsterdam. They also teach at the UAS Amsterdam in the faculty of Business and Economics. Martha Meerman is the head and founder of the research group HRM at the University of Applied Sciences in Amsterdam. Study succes and diversity have been research topics pursued by the authors and the research group for a long time.

\section{Acknowledgements}

NA.

\section{Competing interests}

We have read and understood the journan's policy on declaration of competiing interests. The authors declare that they have no competing interests.

\section{Availability of data and materials}

All materials described in the manuscript, including all raw data, are freely available to any scientist wishing to use them for non-commercial purposes, as long as participant confidentiality/anonimity is not breached. Data is available throuh CAREM (l.kerstens@hva.nl) or by contacting the main author of the journal (d.van.middelkoop@hva.nl).The need for maintaining anonimity of both individuals and teachers teams means the data can not be deposited in a publicly available repository.

\section{Consent to participate}

All research subjects consented to participate in the research.

\section{Consent to publication}

All participants were given full anonymity in this research project. As a result, no details, images, or videos relating to individual participants are included in the paper.

\section{Ethics approval}

The research has been conducted in accordance with the Declaration of Helsinki. The utmost care was taken by the researchers to make ensure this. The anonymity and well-being of the research subjects was respected at all times. At the time of research, our University of Applied Sciences did not have an ethical committee for research-instead the research, including its ethical implications, has been discussed and approved prior to the research by the professors of CAREM - the Center for Applied Research on Economics and Management. More information on CAREM can be found at http://www.amsterdamuas.com/carem. For more information about the ethical approval, Lucy Kerstens, coordinator of CAREM, can be contacted: I.kerstens@hva.nl

Received: 8 September 2016 Accepted: 29 December 2016

Published online: 17 January 2017

\section{References}

Altbach PG, Liz L, Reisberg LE (2009) Trends in global higher education: tracking an academic revolution. A report prepared for the UNESCO 2009 world conference on higher education. Boston College Center for International Higher Education Chestnut Hill, Boston

Andersen ML, Collins PH (1995) Race, class, and gender: an anthology, 6th edn. Wadsworth, New York

Ashton PT, Webb RB (1986) Making a difference: teachers' sense of efficacy and student achievement. Longman Group United Kingdom, New York

Beerkens-Soo M, Vossensteyn H (2009) Higher education issues and trends from an international perspective: report prepared for the veerman committee. Center for Higher Education Policy Studies, The Netherlands

Beulens B, Burger J, van den Brakel J (2015) Predictive inference for non-probability samples: a simulation study. Discussion paper 2015-2013. Heerlen, CBS

Bourdieu P, Passeron JC (1990) Reproduction in education, society and culture, 2nd edn. Sage, London

Bowles S, Gintis H (2002) The inheritance of inequality. J Econ Perspect 16(3):3-30

Bowles S, Gintis H, Groves MO (2009) Unequal chances: family background and economic success. Princeton University Press, Princeton

Cabello B, Burstein ND (1995) Examining teachers' beliefs about teaching in culturally diverse classrooms. J Teach Educ 46(4):285-294 
Carey Kevin (2008) Graduation rate watch: making minority student success a priority. Education Sector Reports, Washington

CBS (2013) Statline, Kerncijfers Hoger Onderwijs. Internet: http://www.cbs.nl

CBS (2016) Statline, Kerncijfers Hoger Onderwijs. Internet: http://www.cbs.nl

Cox T (2001) Creating the multicultural organization: a strategy for capturing the power of diversity. Jossey-Bass, San Francisco

Crul MRJ, Schneider J, Lelie F (2013) Super-diversity—a new perspective on integration. VU University Press, Amsterdam

Cummings A, Zhou J, Oldham GR (1993) Demographic differences and employee work outcomes: effects on multiple comparison groups. Paper presented at the annual meeting of the academy of management, Atlanta

de Jong M (2014) Diversiteit in het hoger onderwijs—over allochtoon en autochtoon. Noordhoff, Houten

Gay G (2002) Preparing for culturally responsive teaching. J Teach Educ 53(2):106-116

Gay G (2010) Acting on beliefs in teacher education for cultural diversity. J Teach Educ 61(1-2):143-152

Gay G (2013) Teaching to and through cultural diversity. Curric Inq 43(1):48-70

Gorashi H (2006) Paradoxen van culturele erkenning - management van diversiteit in Nieuw Nederland. Tijdschrift voor Genderstudies 2006-4:42-53

Hattie JAC (2009) Visible learning: a synthesis of over 800 meta-analyses relating to achievement. Routledge, London

Helms JE (1990) Black and white racial identity: theory, research, and practice. Greenwood Press, New York

Jackson SE, May KE, Whitney K (1995) Understanding the dynamics of diversity in decision making teams. In: Guzzo RA, Salas E (eds) Team effectiveness and decision making in organizations. Jossey-Bass, San Francisco, pp 204-261

Marzano RJ (2003) What works in schools: translating research into action, 1st edn. Association for Supervision \& Curriculum Development, Alexandria

Meerman M, Spierings J, Segers J, Bay N (2009) Een Ontwikkeling in Kleur. Docenten leren op de werkplek omgaan met het multiculturele beroepsonderwijs Hogeschool van Amsterdam: Economie en Management/HES

Meerman M, Gründemann R, Binkhorst J, Çelik G, Hunkar A, Jong M, Middelkoop D, Vos M, Vries S (2013) Etnische Diversiteit in Docententeams in Het Hbo. Hogeschool van Amsterdam/Hogeschool Utrecht/Hogeschool Inholland/ Hogeschool Windesheim, Amsterdam

Meeuwisse M (2012) Being smart is not enough: the role of psychological factors in study success of ethnic minority and ethnic majority students. Erasmus University, Rotterdam

Milliken FJ, Martins LL (1996) Searching for common threads: understanding the multiple effects of diversity in organizational groups. Acad Manag Rev 21(2):402-433

Muhammad A (2015) Overcoming the achievement gap trap: liberating mindsets to effect change. Solution Tree, Bloomington

Nieto S (1992) Affirming diversity: the socio-political context of multicultural education. Longman, New York

Nussbaum MC (2011) Creating capabilities. Harvard University Press, Harvard

Pajares MF (1992) Teachers' beliefs and educational research: cleaning up a messy construct. Rev Educ Res 62(3):307-332

Pels D (2007) De Economie Van De Eer. Een Nieuwe Visie Op Verdienste En Beloning. Ambo, Amsterdam

Roberson QM (2006) Disentangling the meanings of diversity and inclusion in organizations. Group Organ Manag 31(2):212-236

Roberson QM (ed) (2013) Oxford handbook of diversity and work. Oxford University Press, New York

Severiens S (2011) Studiesucces in De Bachelor: Drie Onderzoeken Naar Factoren Die Studiesucces in De Bachelor Verklaren. Risbo, Rotterdam

Shavit Y, Arum R, Gamoran A (2007) Stratification in higher education: a comparative study. Stanford University Press, Redwood

Snook I, O'Neill J, Clark J, O'Neill AM, Openshaw R (2009) Invisible learnings?: a commentary on john hattie's book-'visible learning: a synthesis of over 800 meta-analyses relating to achievement'. N Z J Educ Stud 44(1):93

Snowden M (2004) Learning communities as transformative pedagogy: centering diversity in introductory sociology. Teach Sociol 32(3):291-303

Thompson AG (1984) The relationship of teachers' conceptions of mathematics and mathematics teaching to instructional practice. Educ Stud Math 15(2):105-127

Thompson CE, Carter RT (eds) (1997) Racial identity development theory: applications to individual, group and organizations. Lawrence Erlbaum Associates, Hillsdale

Tsui AS, Egan TD, O'Reilly CA (1992) Being different: relational demography and organizational attachment. Adm Sci Q 37:549-579

van den Broek LM(2009) De Ironie Van Gelijkheid—Over Etnische Diversiteit Op De Werkvloer. Ridderprint, Tilburg van Middelkoop D, Meerman M (2014) Studiesucces En Diversiteit-En Wat HBO Docenten Daarmee Te Maken Hebben. HVA-CAREM, Amsterdam

van Middelkoop D, Meerman M (2015) Coping with international migration and diversity — how do teacher teams in dutch higher vocational education relate to their diverse student population? In how global migration changes the workforce equation. Cambridge Scholars Publishing, Cambridge

Verhaeghe P (2011) De Effecten Van Een Neoliberale Meritocratie Op Identiteit En Interpersoonlijke Verhoudingen. Oikos 56(1):4-22

Vouyoukas CA (2002) Teachers' attitudes towards educational equality and the relationship between these attitudes and their classroom behaviour: a Greek study. Institute of Education, University of London, London

Waslander S (2006) Het Onderwijs: Over Kansen En Kiezen. In: de Beer P, van der Meer J, Pekelharing P (eds) Gelijk! Over De Noodzakelijke Terugkeer Van Een Klassiek Ideaal. van Gennip/De Balie, Amsterdam

Wolff RP (2013) Presteren Op Vreemde Bodem: Een Onderzoek Naar Sociale Hulpbronnen En De Leeromgeving Als Studiesuccesfactoren Voor Niet-Westerse Allochtone Studenten in Het Nederlandse Hoger Onderwijs (1997-2010). Risbo, Rotterdam

Yang Y, Montgomery D (2013) Gaps or bridges in multicultural teacher education: a Q study of attitudes toward student diversity. Teach Teach Educ 30:27-37 
Zepke N, Leach L (2007) Improving student outcomes in higher education: New Zealand teachers'views on teaching students from diverse backgrounds. Teach High Educ 12(5-6):655-668

Zijlstra W, Hendril A, Ahlam A, Mary TW (2013) Generiek is Divers-Sturen Op Studiesucces in Een Grootstedelijke Context Internet: http://universonline.nl/wp-content/uploads/2013/11/RapportG5evaluatie2013.pdf

Submit your manuscript to a SpringerOpen ${ }^{\circ}$ journal and benefit from:

- Convenient online submission

- Rigorous peer review

- Immediate publication on acceptance

- Open access: articles freely available online

- High visibility within the field

- Retaining the copyright to your article

Submit your next manuscript at $\boldsymbol{\nabla}$ springeropen.com 